\title{
Testicular torsion based on material from the Department of Paediatric Surgery, Urology and Traumatology at Wladyslaw Buszkowski Children's Hospital in Kielce during 2008-2013
}

\section{Skręt jądra w materiale Oddziału Chirurgii, Urologii i Traumatologii Dziecięcej Wojewódzkiego Specjalistycznego Szpitala Dziecięcego im. Władysława Buszkowskiego w Kielcach w latach 2008-2013}

\author{
Roman Sławek ${ }^{1}$, Wojciech Niedziela ${ }^{1}$, Przemysław Wolak ${ }^{1,2}$ \\ 'Department of Paediatric Surgery, Urology and Traumatology, Wladyslaw Buszkowski Children's Hospital, Kielce, Poland \\ Head of Department: Przemysław Wolak MD, PhD \\ 2Department of Anatomy, Institute of Nursing and Obstetrics, Faculty of Health Sciences, Jan Kochanowski University, \\ Kielce, Poland \\ Head of Department: Andrzej Wincewicz MD, PhD, Prof. JKU
}

Studia Medyczne 2014; 30 (2): 90-92

Key words: testicular torsion, spermatic cord torsion, child, abdominal pain, acute scrotum.

Słowa kluczowe: skręt jądra, skręt powrózka nasiennego, dziecko, ból brzucha, zespół „ostrej” moszny.

\begin{abstract}
Introduction: Among the causes of acute scrotum syndrome, testicular torsion undoubtedly causes the most serious consequences. The remaining aetiological factors are torsion of the testicular appendages and of the epididymis, epididymo-orchitis, testicular injury, incarcerated inguinal hernia, acute testicular hydrocele and idiopathic scrotal oedema. Torsion of the testis occurs as a result of a twisting of the testis around the vertical axis. This leads to venous occlusion and subsequently to arterial occlusion with ischaemia and necrosis of the gonad.

Aim of the research: Determination of the possibilities of saving the testicle after torsion of the gonad.

Material and methods: Sixty-eight cases of testicular torsion were analysed in boys aged 0-18 years who were treated during the period 2008-2013 in the Department of Paediatric Surgery, Urology and Traumatology in Kielce. The evaluation determined whether or not the gonad could be saved. The degree of macroscopically evident testicular necrosis was determined and the decision made concerning the saving or resecting the gonad. Further development of the saved testicle was monitored ambulatorily.

Results: In 39 patients the testicle was removed due to necrosis, while in the remaining cases the gonad was saved. Torsion of the left testicle was more frequently observed. The symptoms of the torsion were: testicle pain, nausea and vomiting and, more rarely, abdominal pain. The symptoms occurred from $2 \mathrm{~h}$ to several days before reporting to hospital. Emergency surgery was performed. After the surgery ultrasonographic control covered the assessment of blood flow, echostructure and dimensions of the saved gonad (due to the possibility of atrophy after torsion).

Conclusions: A patient who reports pain in the scrotal region should be approached as an emergency case, requiring immediate diagnostics and, very often, emergency surgical management. USG examination with the assessment of intratesticular vascular flow is a standard additional examination in the differential diagnostics of acute scrotum syndrome. Evaluation of the testicles is a necessary element of physical examination in all boys with abdominal pain.
\end{abstract}

\section{Streszczenie}

Wprowadzenie: Najpoważniejszą w skutkach przyczyną zespołu ostrej moszny jest niewątpliwie skręt jądra. Do pozostałych czynników etiologicznych zalicza się: skręt przyczepków jądra i najądrza, zapalenie jądra i najądrza, uraz jądra, uwięźnięcie przepukliny pachwinowej, ostry wodniak jądra oraz idiopatyczny obrzęk moszny. Do skrętu jądra dochodzi w następstwie jego obrotu w osi pionowej. Powoduje to zaciśnięcie naczyń krwionośnych, co prowadzi początkowo do niedokrwienia, a następnie martwicy gonady.

Cel pracy: Określenie możliwości zachowania jądra po dokonanym skręcie gonady.

Materiał i metody: Analizie poddano 68 przypadków skrętu jądra u chłopców w wieku 0-18 lat leczonych w latach 20082013 na Oddziale Chirurgii, Urologii i Traumatologii Dziecięcej w Kielcach. Oceniono możliwość zachowania gonady. Określano śródoperacyjnie stopień widocznej makroskopowo martwicy jądra, podejmując decyzję o zachowaniu lub usunięciu gonady. Dalszy rozwój pozostawionego jądra monitorowano ambulatoryjnie. 
Wyniki: U 39 pacjentów z powodu martwicy jądro usunięto, w pozostałych przypadkach gonadę zachowano. Częściej stwierdzano skręt jądra lewego. Objawami skrętu były: ból jądra, nudności i wymioty, rzadziej ból brzucha. Objawy występowały od 2 godzin do kilkunastu dni przed zgłoszeniem się do szpitala. Zabieg chirurgiczny wykonywano w trybie pilnym. Podczas kontroli ultrasonograficznej po zabiegu oceniano przepływ krwi, echostrukturę i wymiary pozostawionej gonady (możliwość zaniku po skręcie).

Wnioski: Pacjenta zgłaszającego dolegliwości bólowe w obrębie moszny należy traktować jako przypadek ostry, wymagający natychmiastowej diagnostyki i bardzo często leczenia operacyjnego w trybie pilnym. Badanie USG z oceną przepływu naczyniowego w jądrach jest standardowym badaniem pomocniczym w diagnostyce różnicowej zespołu ostrej moszny. Ocena jąder jest koniecznym elementem badania fizykalnego u wszystkich chłopców z bólem brzucha.

\section{Introduction}

Among the causes of acute scrotum syndrome, testicular torsion undoubtedly causes the most serious consequences. The remaining aetiological factors are torsion of the testicular appendages and of the epididymis, epididymo-orchitis, testicular injury, incarcerated inguinal hernia, acute testicular hydrocele and idiopathic scrotal oedema. Torsion of the testis occurs as a result of a twisting of the testis around the vertical axis. This leads to venous occlusion and subsequently to arterial occlusion with ischaemia and necrosis of the gonad.

\section{Aim of the research}

The aim of the study was to determinate of the possibilities of saving the testicle after torsion of the gonad.

\section{Material and methods}

The study included boys treated due to testicular torsion in the Department of Paediatric Surgery, Urology and Traumatology at the Children's Specialist Hospital in Kielce during the period from 1 July 2008 to 31 December 2013. The analysis covered the following: time from the occurrence of symptoms to the moment of the patient reporting to hospital and to the beginning of surgical procedure, complaints reported at admission, results of colour Doppler ultrasound of the testes, types of surgical procedures performed (removal or detorsion of the testicle and saving the gonad, and securing the testicle on the other side into place) and extent of testicular necrosis. During the post-operative period further development of the testicles was ambulatorily monitored - ultrasound examinations were performed which, in an objective way, provided information concerning the size of the gonads, their vascularization and echostructure.

\section{Results}

During the period 2008-2013, 68 patients were treated due to testicular torsion in the Department of Paediatric Surgery, Urology and Traumatology at the Children's Specialist Hospital in Kielce, including 7 newborns. In 39 patients the gonad was removed, and in 29 the gonad was left after detorsion. In the majority of patients, typical symptoms of acute scrotum were observed: in 60 cases testicular pain, which constituted $88 \%$ of the patients in the study; nausea and vomiting in 26 patients (38.2\%); abdominal pain in 11 boys; and in single cases elevated body temperature. In physical examination, enlargement and firm texture of the abnormal testicle was seen, as well as tenderness. Brunzel's sign, i.e. elevation of the affected testicle towards the upper scrotum and the thickening of the spermatic cord, was noted in $80 \%$ of patients, and skin pitting at the scrotal base (Ger's sign) was seen in $2 / 3$ of the patients. In $1 / 3$ of the patients, laboratory tests showed elevated leucocytosis. Ultrasound examination with the assessment of interstitial vascular flow by the Doppler method showed lack of blood flow in the testicle, enlargement of the gonad, disturbed echostructure, thickening of the tunica albuginea, location of spermatic cord torsion and calcifications. Clear flows in the tissues surrounding the testicle were observed. In 5 patients, a slight flow was noted despite the torsion of the testicle. Seventeen patients reported to hospital within $6 \mathrm{~h}$ of the occurrence of symptoms, and in all of them the testicle was saved (Figures 1 and 2). Within the subsequent 6-24 h 18 patients reported to hospital (the gonad was saved in 12), and the remaining patients (39) reported after $24 \mathrm{~h}-$ all patients in this group had orchiectomy performed due to macroscopic features of testicular necrosis. In each of these cases, the contralateral gonad was prophylactically fixed to the scrotal septum. Emergency

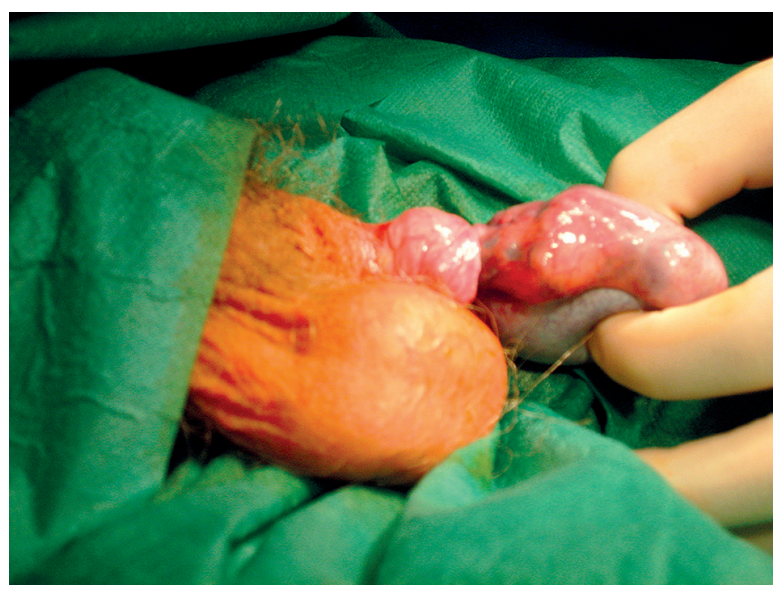

Figure 1. Torsion of the left testis 


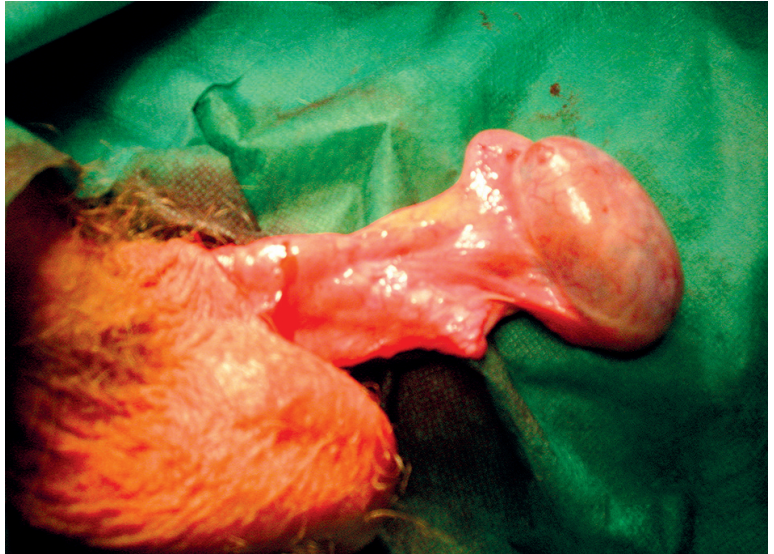

Figure 2. Detorsion of the left testis in the same patient

surgical procedures were performed after carrying out the necessary diagnostics. In 34 cases, the patients were operated on within one hour from admission. A longitudinal incision was performed, parallel to the raphe of scrotum at the side of the abnormal gonad, while in the case of evident macroscopic features of necrosis the gonad was removed. In the remaining cases, the testicle was evaluated after detorsion, heating with a warm saline water solution and injecting $0.5 \%$ lignocaine solution around the spermatic cord. In the post-operative course, in 50 cases an antibiotic was applied intravenously (of these, 28 cases resulted in excision of the testicle). The mean duration of hospitalisation was 3.4 days, which did not depend on the type of procedure. In the post-operative course, in 1 patient with the gonad left unexcised, atrophy of the testicle was observed, confirmed by ultrasound examination. The fertility of the patients who had undergone surgery due to testicular torsion was not examined.

\section{Discussion}

Testicular torsion is one of the causes of acute scrotum, and should be differentiated from torsion of the testicular appendages and of the epididymis, epididymo-orchitis, testicular cancer, testicular injury and idiopathic scrotal oedema [1]. Apart from intense testicular pain, torsion of the testicle may be accompanied by nausea, vomiting and, more rarely, abdominal pain. While examining patients who report abdominal pain complaints, it is always necessary to evaluate the testicles [2]. A routine additional test in the case of suspicion of testicular torsion is ultrasound examination with determination of blood flow in the testicular vessels. In some patients the result of this examination may be false positive, which is emphasised in the studies by Arce (in a group of operated patients with the diagnosis of intraoperatively observed testicular torsion, blood flow was found in ultrasound examination) [3]. In every case of suspicion of testicular tor- sion the decision to undertake surgical treatment is necessary. It should be remembered that after several hours of testicular ischaemia, anti-testicular antibodies develop, which also destroy the untwisted testicle, leading to the patient's infertility [4]. In the case of macroscopically confirmed necrosis, when the symptoms persisted for at least $24 \mathrm{~h}$ before the surgery, all the gonads were removed. A separate problem is foetal testicular torsion. When it is not accompanied by the inflammatory state concerning the scrotum or testicle, there are no indications for emergency surgery [5]. Surgical treatment and the need for contralateral testicular fixation is a controversial problem. The 'blind' fixation of the sutures attaching the contralateral testicle to the scrotum may damage the vascularisation of the gonad. It is recommended to fix the testicle to the scrotum in every case of testicular detorsion, as a prophylactic measure [6]. After the removal of the testicle, all patients aged over 15 years are offered implantation of a testicular prosthesis. Such a procedure is also offered in our centre.

\section{Conclusions}

A patient who reports pain in the scrotal area should be approached as an emergency case, requiring immediate diagnostics and, very frequently, emergency surgical treatment. The USG examination with the assessment of vascular flow in the testicles is a standard additional examination in the differential diagnostics of acute scrotum syndrome. Evaluation of the testicles is a necessary element of physical examination in all boys with abdominal pain.

\section{References}

1. Murphy FL, Fletcher L, Pease P. Early scrotal exploration in all cases is the investigation and intervention of choice in the acute paediatric scrotum. Pediatr Surg Int 2006; 22: 413-6.

2. Pogorelic Z, Mrklic I, Juric I. Do not forget to include testicular torsion in differential diagnosis of lower acute abdominal pain in young males. J Pediatr Urol 2013; 9: 1161-5.

3. Arce JD, Cortes M. Vargas Sonographic diagnosis of acute spermatic cord torsion. Pediatr Radiol 2002; 32: 485-91.

4. Taskinen S, Taskinen M, Rintala R. Testicular torsion: orchiectomy or orchiopexy? J Pediatr Urol 2008; 4: 210-3.

5. Cuervo JL, Grillo A, Vecchiarelli C, et al. Perinatal testicular torsion: a unique strategy. J Pediatr Urol 2007; 42: 699-703.

6. Antao B, MacKinnon AE. Axial fixation of testes for prevention of recurrent testicular torsion. Surgeon 2006; 4: 20-1.

\section{Address for correspondence:}

Roman Sławek MD

Departament of Paediatric Surgery,

Urology and Traumatology

Wladyslaw Buszkowski Children's Hospital

ul. Langiewicza 2, 25-381 Kielce, Poland

Phone: +48413615525 ext. 323

E -mail: romi20@wp.pl 